\title{
HS 578T
}

National Cancer Institute

\section{Source}

National Cancer Institute. HS 578T. NCI Thesaurus. Code C117225.

An adenocarcinoma cell line established by A.J. Hackett, et al. from a 74 year old

Caucasian female patient with breast carcinoma. 